\title{
Audit committees, non-audit services, and auditor reporting decisions prior to failure
}

\author{
Chloe Yu-Hsuan Wu ${ }^{\mathrm{a}}$, Hwa-Hsien Hsu ${ }^{\text {* }}$, Jim Haslam ${ }^{\mathrm{c}}$ \\ ${ }^{a}$ Hull University Business School, University of Hull, Hull, UK \\ ${ }^{\mathrm{b}}$ Bradford University School of Management, University of Bradford, Bradford, UK \\ ${ }^{\mathrm{c}}$ Newcastle University Business School, University of Newcastle, Newcastle upon Tyne, UK
}

\section{Abstract}

This study investigates the associations between audit committee characteristics and the likelihood of auditors' going-concern decisions among UK failed firms. Specifically, we examine whether the threat posed by auditor-provided non-audit services (NAS) to auditors' reporting decisions is mediated by audit committee characteristics. We find that failed firms with higher proportions of independent non-executive directors (NEDs) and financial experts on the audit committee are more likely to receive auditor going-concern modifications prior to failure, but that there is no significant relationship between NAS fees and the likelihood of receiving a going-concern modification. The evidence further suggests that the association between NAS and auditors' reporting decisions is subject to audit committee characteristics.

Where the audit committee is more independent and includes a greater proportion of financial experts, auditors providing the client with NAS are less likely to issue a standard unmodified going-concern report prior to failure. Overall, the findings provide support for corporate

\footnotetext{
*Corresponding Author. Bradford University School of Management, Emm Lane, Bradford, BD9 4JL, UK. Tel: +44 (0)1274234343; Fax: +44 (0)1274235837.

Email addresses: h.hsu1@bradford.ac.uk (H. Hsu)

** We would like to thank A. Rashad Abdel-khalik, Alnoor Bhimani, Charlie Cai, Yuan Ding, Kevin Keasey, Robert Knechel, Martin Leob, David Mccollum-Oldroyd, Chen Su, Francesco Vallascas, Ann Vanstraelen, Chengang Wang, Pauline Weetman, conference participants at the 2012 British Accounting \& Finance Association Meeting in Brighton, the 2013 European Accounting Association Meeting in Paris, and all seminar participants at the University of Hull and the University of Bradford for helpful comments and suggestions on earlier versions of the article.
} 
governance regulators' concerns about the monitoring benefits of audit committee independence and the presence of financial expertise on the audit committee for auditors' reporting decisions.

Keywords: Audit committee; Corporate governance; Non-audit services fees; Going-concern report; Corporate failure. 


\section{Introduction}

The study investigates associations between audit committee characteristics and the likelihood of auditor decisions to issue a modified going-concern report ${ }^{1}$ in the context of UK failed firms. And in relation thereto we analyze whether reporting decisions made by auditors providing non-audit services (NAS) are mediated by those audit committee characteristics, thus investigating the combined effects of auditor-provided NAS and audit committee characteristics on auditor reporting decisions.

The research investigations carried out here are justified for a number of reasons. The audit committee, on the face of it, is positioned so as to impact on auditor reporting decisions. It is charged to review and monitor the external auditor's independence and objectivity, the effectiveness of the audit process and the value of auditor-provided NAS. And the audit committee has the responsibility to make recommendations on the appointment, reappointment and removal of the external auditors (UK Corporate Governance Code, 2012).

From the agency perspective, it has been assumed that the presence of independent directors and financial experts on the audit committee substantively enhances audit committee effectiveness in monitoring and controlling financial reporting and the external audit - as

\footnotetext{
${ }^{1}$ Hereafter, we refer to a modified going-concern report as auditor reporting opinion in relation to the going-concern status of the entity including qualified opinions, adverse opinions, disclaimers for going-concern issues (International Standard on Auditing (ISA) 705) and unqualified opinions with an emphasis of matter paragraph highlighting the existence of material going-concern uncertainty (ISA 570). This array of modifications groups together reports differentiable in terms of auditor judgment about the pervasiveness of the effect, or possible effect, on the financial statements (see ISA 705). Nevertheless, all these modifications would typically indicate a negative view in respect of going-concern as compared to the standard going-concern assumption.
} 
independent directors and financial experts are assumed to be personnel of high calibre with strong incentives to monitor the financial reporting process (e.g., Klein, 2002; Krishnan, 2005).

Theoretical perspectives on the impact of auditor-provided NAS lead to more of an open question as to whether and when auditor-provided NAS is likely to impair or improve auditor reporting decisions. The dominant perspective points to impairment as auditor-provided NAS are seen to potentially threaten and compromise auditor objectivity and independence: often the consulting nature of NAS places the auditors in roles where they work closely with management; the corresponding fees tend to increase the auditors' economic ties with their audit clients (DeFond, Raghunandan, \& Subramanyam, 2002). ${ }^{2}$ An alternative view, relying on the knowledge spillover effect, points in a different direction: the provision of NAS is seen to give the auditors more in-depth understanding of their clients, which also benefits the audit (Simunic, 1984; Palmrose, 1986). It is thus not so surprising that prior empirical studies have provided mixed results (e.g. DeFond et al., 2002; Basioudis, Papakonstantinou, \& Geiger, 2008).

\footnotetext{
${ }^{2}$ Such matters and considerations may at least create dilemmas for external auditors. The going-concern opinion can be a direct outcome of an auditor's ostensibly professional decision, but translating this into a report may be understood to involve a negotiation of the auditor, management and audit committee. Many see the potential for tension here, particularly the possibility that corporate management may pressurize the auditor not to issue an unfavorable opinion, which could, e.g., impact on the share price (see Citron et al. 2008; Menon \& Williams, 2010; Blay \& Geiger, 2013). Such tension potentially puts at stake auditor income streams: while replacing auditors can attract to the company the negative attention of the market, there is documented evidence that auditors are more likely to be replaced after issuing a going-concern modification - indeed potentially the outcome can be the losses of benefits accruing to the auditor generated by all their work for the client, leaving aside other reputational effects (see Carcello \& Neal, 2003). Further, for Sharma and Sidhu (2001), a firm facing impending failure has an enhanced need for NAS, giving the auditors further incentives to delay a going-concern modification.
} 
Given that audit committees are charged with assessing the costs and benefits of auditor-provided NAS, and given that independent directors and financial experts have incentives to monitor and are more capable of overseeing the purchase of auditor-provided NAS, a further perspective of interest is that the influence of auditor-provided NAS on auditor reporting is potentially mediated by audit committee characteristics.

Furthermore, prior empirical research in these areas is relatively scarce. Although a growing number of research papers have attempted to investigate the relationships between audit committee characteristics and managerial discretion in financial reporting (e.g., in terms of earnings management and the level of accounting disclosure), little is known regarding the effects of those characteristics on auditor reporting decisions. We therefore extend the existing corporate governance literature to address this issue in the context prior to failure. Some studies have examined the influence of the audit committee on auditor-provided NAS (e.g. Abbott, Parker, Peters, \& Raghunandan, 2003; Zaman, Hudaib, \& Haniffa, 2011) but little is known about whether the inter-relationship affects auditor reporting decisions. Again, we extend the literature in this respect.

We can also note here, providing further motivation for our study, the existence of continuing public policy debates in areas related to the focuses of this study. There is the continuing concern of regulators, reported often in prior literature, about the majority of failed companies failing in the absence of a timely auditor opinion indicating going-concern 
uncertainty (see House of Lords, 2011; The Sharman Inquiry, 2012). ${ }^{3}$ A series of corporate failings over the last two decades has intensified regulatory concerns about auditor-provided NAS and audit committees' responsibility in respect of monitoring this area. An auditor's going-concern modification in this respect is considered useful information to feed into company appraisal including in terms of appreciation of the increased likelihood or risk of impending corporate failure. The absence of a timely going-concern modification prior to corporate failure is often cited as evidence of audit failure and is often linked both to weak corporate governance and to auditor-provided NAS. Since auditors are charged with the responsibility to assess an entity's going-concern risk and to identify events or conditions that may cast significant doubt on an entity's ability to continue as a going concern (International Standard on Auditing (ISA) 570), the decision not to modify the going-concern assumption in the audit report issued immediately prior to failure raises eyebrows and motivates further reflection as part of an attempt to explore and assess auditing and corporate governance including the role of the audit committee - in practice (The Sharman Inquiry, 2012). ${ }^{4}$ To

\footnotetext{
${ }^{3}$ For example, Citron and Taffler (1992) and this study report that only $26.2 \%$ and 34\%, respectively, of UK failing firms had received an auditor's modified report for going-concern uncertainties. Research has found that around one half of US bankrupt firms had received such a report (Mutchler et al., 1997; Feldmann \& Read, 2010).

${ }^{4}$ It should be noted that none should hold it reasonable to expect auditors to foresee all instances of failure. Likewise, a decision not to modify the going-concern assumption cannot be taken to guarantee company survival. There are dangers of resting upon or coming too close to such positions even among policy-makers and academics. More reasonable here, however, consistent with the substance of prior literature, is the position that auditors can potentially make decisions along a spectrum of reasonable, independent and expert decisions (or unreasonable and poor decisions) based on practices of varying degrees of reasonableness and expertise that influence the audit report's usefulness vis-à-vis appreciations of corporate failure likelihood (see Defond et al., 2002). Prior literature suggests the manifestation of corporate failure the more appropriate context for analysis of the determinants of and appraisal of the auditor's going-concern report because within a year prior to failure the typical failing company shows relatively unambiguous financial distress symptoms that are more likely to have reached the threshold of going-concern uncertainty to merit modification (Hambrick \& D'Aveni, 1988;
} 
address the concerns, corporate governance reformers have considered the audit committee as having a central role (e.g., Smith Report, 2003; UK Corporate Governance Code, 2012).

This study, focusing upon UK failed companies in a recent period - targeting the population of non-financial failed firms with an audit committee between 1997 and 2010 yields interesting results. It is found that only $34 \%$ of the UK failed firms analyzed received auditor going-concern modifications for their last financial statements. The empirical findings indicate that failed firms with a higher proportion of independent NEDs and a higher proportion of financial experts on the audit committee are more likely to receive auditor going-concern modifications. The study found no significant relationship between auditor-provided NAS fees and the likelihood of receiving a going-concern modification. Further evidence, however, indicates that the association between auditor-provided NAS and auditor reporting decisions is conditional on audit committee characteristics. The interaction terms between auditor-provided NAS fees and the percentages of independent NEDs and financial experts on the audit committee are positively related to the likelihood of a going-concern modification. This finding suggests that where the audit committee is more independent and includes a greater proportion of financial experts, auditors providing the client with NAS are less likely to issue an unmodified going-concern report prior to failure. 
This study seeks to contribute to the existing literature in a number of ways. As indicated above, the paper's attention to the effect of audit committee characteristics on audit reporting decisions in the context prior to failure has so far been scarcely researched. And, similarly, little is known about the joint effect of auditor-provided NAS and audit committee characteristics on auditor reporting decisions, which is also focused upon here. The study here hence addresses significant gaps in the literature.

A further contribution is in the focus on the UK setting. Virtually all prior studies have been US-based, raising questions as to the generalizability to other environments. Further, while precise differences between the US and the UK in relevant regulatory systems and in their applications in their respective contexts is a matter of debate, involving as it does substantial complexity and critical interpretation, the UK setting is clearly different and dimensions of these differences appeal in relation to the focuses of this study (Hudaib \& Cooke, 2005). The UK setting offers several advantages and potentially provides for new insights in respect of seeking to appraise the role of the audit committee and auditor-provided NAS with regard to audit reporting. UK companies, compared to US counterparts, arguably have relatively more flexibility to decide their audit committee structure to the extent that compliance with the applicable UK corporate governance code (UK Corporate Governance Code, 2012) is on a 'comply or explain’ basis - whereby a company complies to various recommendations/provisions or provides explanations for what amounts to non-compliance 
(Arcot, Bruno, \& Faure-Grimaud, 2010) ${ }^{5}$. For Arcot et al. (2010), there is an absence of a formal enforcement here - monitoring is in effect delegated to investors, market participants and public opinion. In addition, there is no blanket ban on NAS in the UK, where companies have freedom to choose their preferred source of advice and thus the audit committee may play a more important role in monitoring the purchase of NAS. There is a relevant standard of ethics but this is more in the nature of a guideline (APB Ethical Standard 5). Thus, while the UK approach is far from a free for all, and its commitment to a principles-based rather than a rules-based approach is potentially consistent with a highly sophisticated and appropriate regulatory functioning, this commitment arguably does usher in a relative degree of liberalism. That the environment of the UK is arguably in at least some respects more flexible than is the case in the US may thus enable us to examine how variations in audit committee composition and auditor-provided NAS and their combined effect impact upon audit reporting decisions. Further, the litigation environments of the UK and the US differ markedly (Hudaib \& Cooke, 2005). These differences and the lower litigation risk in the UK, as compared to the situation in the US, may mediate audit practice (Seetharaman, Gul, \& Lynn, 2002; Khurana \& Raman, 2004). As discussed above, a going-concern opinion results from a negotiation involving the auditor, management and audit committee. Analysis of

\footnotetext{
${ }^{5}$ A flexible 'comply or explain' approach to corporate governance was adopted in the UK in preference to more prescriptive legislative regulation with the emergence of the Cadbury Code from the Cadbury Report of 1992. This basic approach was retained in various attempts to improve upon Cadbury - the Greenbury Code of 1995, the Combined Code of 1998 and now the UK Corporate Governance Code of 2012. The approach, and hence currently the 2012 Code, has been appended into UK Stock Exchange Listing Rules from 1998 (see Arcot et al., 2010).
} 
indications of the effectiveness of audit committees with differing characteristics vis-à-vis auditor reporting decisions may be fruitful in a relatively liberal and less litigious environment. There are enough reasons here for finding the UK an interesting and important focus for analysis beyond the point that the analysis is an addition to the relatively few previous studies that have been mainly US based.

The remainder of this study is structured as follows. In the following section, we overview the prior literature concerning auditors' going-concern decisions and develop our hypotheses. The sample selection procedure and research design are described in Section 3. The results are then presented and discussed. The final section draws conclusions.

\section{Background and hypothesis development}

\subsection{Background}

The going-concern assumption is an important one in the preparation of financial statements. The issue addressed in deciding upon the validity of the assumption is whether the entity will continue in operational existence for the foreseeable future (ISA, 570). ${ }^{6}$ According to ISA 570, auditors are responsible for assessing the going-concern status of their client and highlighting the existence of a material uncertainty regarding an entity's ability to continue as a going concern in their audit reports. An auditor's going-concern modification is

\footnotetext{
${ }^{6}$ As defined by ISA 1, the normal time span for the auditor to consider the appropriateness of the going-concern assumption is typically at least 12 months from the end of the reporting period.
} 
therefore recognized in the literature as at least an indicator of increased riskiness in relation to the continuity of a company (Levitan \& Knoblett, 1985; Koh, 1991). Failure to issue a modified opinion in this context may affect the usefulness of financial statements (see Mutchler, Hopwood, \& McKeown, 1997).

The decision to issue a going-concern modification is regarded as one of the most difficult decisions for auditors (e.g., Ruiz-Barbadillo, Gomez-Aguilar, Fuentes-Barbera, \& Garcia-Benau, 2004). In the negotiation process between auditors, top management and the audit committee (Antle \& Nalebuff, 1991; Teoh, 1992), auditors may be confronted by significant pressure from client management, since the issuance of a going-concern modification may lead to serious negative effects on a company's share price (e.g., Citron, Taffler, \& Uang, 2008; Menon \& Williams, 2010) and credit rating (Firth, 1980). In addition, auditors themselves are concerned about what they see as the possible economic consequences of issuing a going-concern modification when making continuity judgments (Kida, 1980): they may fear losing the client and the corresponding fees (e.g., Carcello \& Neal, 2003).

In order to manage any potential erosion of auditors' reporting decisions engendered by inappropriate pressure from audit clients and/or the commercial interests of auditors themselves in the provision of services, corporate governance regulations/codes in several countries highlight the importance of the audit committee in the monitoring of the external 
audit. No similar consensus has been reached, however, regarding whether to ban NAS. The UK corporate governance reformers are not fully persuaded that restricting auditor-provided NAS by outlawing these is necessary on the grounds that companies should have freedom to choose their preferred source of advice (see e.g., Cadbury, 1992; Smith Report, 2003). They develop recommendations aimed at mitigating the potential negative effect of NAS by strengthening the audit committee's role in monitoring the purchase of such services and offering added assurance to the shareholders.

\subsection{Audit committee characteristics and going-concern reporting decisions}

In agency theory a series of mechanisms are proposed that seek to mitigate agency problems arising from the separation of ownership and control (Jensen \& Meckling, 1976). The role of the audit committee here is to ensure that the interests of shareholders are properly protected in relation to financial reporting. One of the prime tasks of the audit committee is to monitor and seek to ensure the objectivity and independence of external auditors, to mitigate management pressure on auditors, and to enhance the integrity of financial statements (Collier \& Gregory, 1996; Pomeroy \& Thornton, 2008; Beasley, Carcello, Hermanson, \& Neal, 2009). According to the Blue Ribbon Committee (1999, p.7), the audit committee is the 'ultimate monitor' of the (financial reporting) process. 
Corporate governance regulators are particularly concerned with audit committee independence (Cadbury, 1992; Smith Report, 2003; UK Corporate Governance Code, 2012; Ghafran \& O'Sullivan, 2012;). The UK Corporate Governance Code (2012) recommends that an audit committee be composed of a minimum of three independent directors. The theoretical support for the importance of independent directors is rooted in agency theory. According to this perspective, independent directors are free from economic interests or personal links with the managers of the company and are therefore better suited to exercising the monitoring task (Fama \& Jensen, 1983). Additionally, independent directors have a stronger motivation to maintain the value of their reputational capital in the external labour market (Fama, 1980). Accordingly, they are deemed likely to play a more effective monitoring role and to have greater incentives to enhance the quality and transparency of financial information disclosed to shareholders (O'Sullivan, 2000).

While serving on a part-time basis enhances independence and is hence in this respect part of the rationale for independent NEDs, it has also been pointed out that as independent directors serve on a part-time basis - and typically serve as directors on multiple boards ${ }^{7}$ they have limited contact with day-to-day corporate affairs and by dint of this are less likely

${ }^{7}$ To ensure that directors are able to contribute sufficient time to the company, the UK governance codes recommend that a full time executive director should not take on more than one non-executive directorship in a FTSE 100 company nor be the chairman of such a company (Smith Report, 2003; UK Corporate Governance Code, 2012). 
to allocate sufficient time to gaining firm-specific knowledge. This aspect may in itself limit the effectiveness of their monitoring duties (see Patton and Barker, 1987).

Prior empirical studies primarily focus on the relationship between audit committee independence and managerial financial reporting decisions but provide mixed results. In the U.S., for example, Klein (2002), Bédard, Chtourou, and Courteau (2004) and Dhaliwal, Naiker, and Navissi (2010) find that there is a negative relationship between the proportion of audit committee members who are independent and earnings management. Further, Abbott, Parker, and Peters (2004) find a negative relationship between the presence of a fully independent audit committee and the likelihood of restatements and financial fraud. Li, Mangena, and Pike (2012), however, find that the quality of intellectual capital disclosure is not associated with audit committee independence in the U.K.

The existing literature on the association between audit committee independence and auditor reporting decisions is limited and virtually all U.S. based (Pomeroy \& Thornton, 2008). Carcello and Neal (2000) find that the presence of a greater proportion of independent directors on the audit committee is positively correlated with auditors' reporting quality. Further, Carcello and Neal (2003) examine whether independent audit committees are more capable of exercising power over management and thus helping auditors to resist pressure from top management. They document that audit committees with high proportions of independent directors are more effective in shielding external auditors from dismissal after a 
modified going-concern opinion is issued. The UK Corporate Governance Code, 2012, considers that the presence of independent directors on the audit committee enhances effectiveness in monitoring audit quality. Therefore, we hypothesize that:

Hypothesis 1: The likelihood of an auditor going-concern modification prior to failure is positively related to the proportion of independent directors on the audit committee.

The presence of financial experts on the audit committee has become an area of key interest in recent research. Audit committee members are expected to manage to understand the complexities of financial reporting, evaluate subjective accounting policies, understand auditors' decisions and appraise the quality of financial reports (Kalbers \& Fogarty, 1993). Financial expertise is deemed crucial to an audit committee's effectiveness because the committee needs to perform numerous duties that require a high level of financial/accounting sophistication (DeFond, Hann, \& Hu, 2005; Zaman et al., 2011). Financial experts are thus important for the fulfilling of those duties and protecting shareholders' interests in relation to financial reporting quality (DeFond et al., 2005).

Some recent studies explore the relationship between audit committee financial expertise and managerial reporting quality. Abbott et al. (2004) find a negative relationship between the presence of financial experts on audit committees and the incidence of financial restatements. Krishnan and Visvanathan (2010) and Dhaliwal et al. (2010) further document 
that audit committee financial expertise is positively associated with earnings quality. In the UK, Mangena and Pike (2005) report a positive relationship between audit committee financial expertise and the quality of interim disclosure. By contrast, Li et al. (2012) do not find a significant association between audit committee financial expertise and the quality of voluntary disclosure.

Similar to audit committee independence, relatively little attention has been paid to the association between audit committee financial expertise and auditor reporting decisions. DeZoort and Salterio (2001) argue that financial experts have better knowledge about the audit process and the auditor's judgments. They find that financial experts on the audit committee are more likely to stand on the auditor's side when there is a dispute between the auditor and management. The UK Corporate Governance Code (2012) also recognizes the importance of financial experts on audit committees and recommends that the audit committee should have at least one member with financial expertise. Accordingly, the second hypothesis is as follows:

Hypothesis 2: The likelihood of an auditor going-concern modification prior to failure is positively related to the proportion of financial experts on the audit committee.

\subsection{Auditor-provided NAS fees and auditor going-concern reporting decisions}


The provision of NAS has continued to be the subject of the most heated debate in relation to auditor reporting quality. The theoretical frameworks predict a multi-dimensional and bi-directional relationship between auditor-provided NAS and auditors’ reporting quality. On the one hand, the provision of NAS reinforces economic bonds between auditors and clients. This may increase auditors' incentives to accommodate client management in order to retain lucrative revenue from the client and thereby impair auditor independence and auditors' reporting quality (DeFond et al., 2002). It is further argued that the provision of NAS alongside audit services increase an auditor's financial dependence on the client, which gives client management a ground to pressurize the auditor to issue a favourable opinion (DeAngelo, 1981; Habib, 2012). In addition, the consulting nature of NAS is likely to place auditors in positions where they work closely with management, potentially reducing their maintaining of the integrity of auditor reporting (DeFond et al., 2002).

On the other hand, it has been suggested that the provision of NAS may strengthen audit quality. The provision of NAS can increase an auditor's knowledge and understanding about its clients and thus enhance the audit (Simunic, 1984; Palmrose, 1986). Auditors are therefore more likely to detect and identify problems of a firm when simultaneously offering both NAS and audit services to a client. In addition, the provision of both NAS and audit services would increase the client's dependence on its auditor's services, which may reduce the threat of being replaced when there is a dispute between auditor and client management (DeAngelo, 
1981). UK corporate governance reformers are not fully persuaded that imposing strict rules limiting NAS is necessary, since, as Cadbury (1992, para. 5.11) put it: "the prohibition (of NAS) would limit the freedom of companies to choose their sources of advice and could increase their costs”.

A number of empirical studies have examined the effects of NAS fees on financial reporting quality by measuring various proxies, such as earnings conservatism, discretionary accruals and the likelihood of restatements (Craswell, Stokes, \& Laughton, 2002; Ferguson, Seow, \& Young, 2004; Ruddock, Taylor, \& Taylor, 2006), but the results are mixed. Inconclusive results are also found regarding the relationship between auditor-provided NAS and the likelihood of receiving going-concern opinions for poorly performing companies in both the U.S. and the U.K. (Lennox, 1999; DeFond et al., 2002; Basioudis et al., 2008; Blay \& Geiger, 2013). Based on a sample of bankrupt firms, Sharma and Sidhu (2001) find a negative relationship between auditor-provided NAS fees and the likelihood of an auditor going-concern modification. The present research extends these studies by examining UK failed firms and hypothesizes:

Hypothesis 3: The likelihood of an auditor going-concern modification is negatively related to the level of NAS fees. 


\subsection{The interactive effect of audit committee characteristics and auditor-provided NAS on}

auditor going-concern reporting decisions

As noted above, auditor-provided NAS may pose a threat to auditors' reporting quality.

Governance reforms therefore typically require that audit committees be responsible for reviewing and monitoring auditor-provided NAS fees paid to the auditor and evaluating whether the economic relation between the client and auditor appears to impair auditor judgment (Cadbury, 1992: para. 5.11; Combined Code, 2003: para. C 3.2; Smith Report, 2003: para. 5.22; UK Corporate Governance Code, 2012). Although the audit committees are charged with these responsibilities, whether they are able to moderate the potential negative effect of auditor-provided NAS fees, and thus improve auditor reporting quality, has not been properly addressed in the literature.

Since the audit committee is involved in the NAS purchase decision, its composition would influence the potential impact of auditor-provided NAS on auditors' reporting quality. According to the agency perspective, independent directors are potentially tough monitors and are more likely to play an effective oversight role on an audit committee because they are free from financial and personal ties with the company and are concerned about their reputational capital in the market (Fama \& Jensen, 1983). Accordingly, independent directors would act to avoid any conflict of interest arising from the closer business relationship associated with auditor-provided NAS. In addition, independent directors on the audit 
committee may bear higher director liability and litigation risk once a financial misstatement occurs. Abbott et al. (2003) therefore argue that independent directors have strong incentives to scrutinise managerial decisions in respect of the purchase of NAS in order to reduce the potential threat to auditors’ reporting quality.

Moreover, financial expertise on the audit committee is also likely to mediate the effect of NAS on auditors' reporting quality. As previously discussed, financial experts are capable of understanding the complexity of financial issues and executing oversight in relation to the financial reporting process. Their professional knowledge enables them to monitor NAS and to evaluate the impact on auditors' reporting quality. Audit committees with financial experts are more likely to disagree with managerial decisions on the purchase of NAS if such services would result in reduced auditor independence (Zaman et al., 2011).

Literature investigating the role of the audit committee in relation to the purchase of NAS is limited. Gaynor, McDaniel, and Neal (2006) provide survey results and suggest that the audit committee would consider the effects of NAS on audit quality in determining whether to approve the purchase of NAS. The audit committee is more likely to approve NAS if a service is perceived to be beneficial to audit quality. Further, Abbott et al. (2003) and Zaman et al. (2011) empirically document a negative association between audit committee independence and auditor-provided NAS fees. Zaman et al. (2011) also find that these fees are negatively related to the presence of financial expertise on the audit committee. From the 
above, and drawing on regulatory recommendations and the literature on audit committee structure and responsibility, we examine the combined effects of audit committee characteristics and auditor-provided NAS fees on auditor reporting quality and propose the following hypotheses:

Hypothesis 4a: The relation between the likelihood of an auditor going-concern modification and auditor-provided NAS fees is less pronounced when the failing company has a more independent audit committee.

Hypothesis 4b: The relation between the likelihood of an auditor going-concern modification and auditor-provided NAS fees is less pronounced when the failing company has a more financially expert audit committee.

\section{Sample selection and research design}

\subsection{Sample selection}

This research investigates the relationship between audit committee independence, auditor-provided NAS fees and the likelihood of going-concern modifications prior to a corporate failure event. The empirical tests are based on a population of failed UK-incorporated, non-financial firms. ${ }^{8}$ Failed firms are identified by investigating all quoted firms delisted from the Official List on the London Stock Exchange over the period

\footnotetext{
${ }^{8}$ Companies in the financial sector were excluded because their financial structure is distinct from other companies and they are often subject to special rules and recommendations.
} 
1997-2010. ${ }^{9}$ A firm is considered failed in this research if the reason for the cancellation of

its listing was its entry into receivership, administration, or liquidation, consistent with the definition adopted by Peel and Peel (1988) and Neophytou and Molinero (2004). ${ }^{10}$

Application of the stated criteria yields a population of 124 firms that failed between the years of 1997 and 2010. However, because an audit committee was not established in all 124 failed firms, the final sample is made up of 116 failed firms. ${ }^{11}$ Table 1 presents the characteristics of the failed sample firms. Panel A presents the number of failures among the sample firms for each year from 1997 to 2010. Panel B presents the distribution of the industrial classifications of the 116 failed firms.

Going-concern opinion and corporate governance data used in this study were collected manually from the annual reports of the failed sample firms. Financial information was collected from the electronic resources of Datastream or FAME.

\footnotetext{
${ }^{9}$ The lists of UK companies revoked from the Official List on The London Stock Exchange are obtained from Citytext or Hemscott Company Guru electronic resources.

${ }^{10}$ Firms were included in the sample if they were transferred from the Official List to the AIM (Alternative Investment Market) List and subsequently delisted from the AIM List between 1997 and 2010 without filing any annual accounts during their AIM listing periods. There are 14 firms in our final sample that were transferred from the Official List to the AIM List between 1997 and 2010. Those firms are considered as official listing firms in this study since they went into receivership, administration or liquidation immediately after moving onto the AIM list, and all of their filed information obtained is from during their official listing periods.

${ }^{11}$ We find in our UK-based study that relatively few large-scale companies have been subject to failure, consistent with the prior relevant study by Citron and Taffler (1992) that employed 107 failed companies between 1977 and 1986. Similarly, there were 89, 134, 134 and 92 failed companies in the relevant U.S. studies by Menon and Schwartz (1987), McKeown, Mutchler, and Hopwood (1991), Hopwood et al. (1994) and Callaghan et al. (2009), respectively.
} 
Insert Table 1 about here

3.2 Regression model and specifications

This research employs logistic analysis to examine the study hypotheses, since the dependent variable, with categories of going-concern modifications or non-going-concern modifications, is dichotomous. The general models are developed as follows:

$$
\begin{aligned}
& G C M=\beta_{0}+\beta_{1} A A_{-} I_{N E D_{i}}+\beta_{2} \text { EXPERT }_{i}+\beta_{3} \text { FEERATIO }_{i}+\beta_{4} A_{\text {AC_SIZ }}+\beta_{5} \text { REPORTLAG }_{i} \\
& +\beta_{6} \text { TENURE }_{i}+\beta_{7} \text { BIGN }_{i}+\beta_{8} \operatorname{LnCOM}_{-} S I Z_{i}+\beta_{9} \mathrm{COMPLEX}_{i}+\beta_{10} \mathrm{LOSS}_{i}+\beta_{11} \mathrm{LEV}_{i} \\
& +\beta_{12} \text { PRIOR }_{i}+\beta_{13} \text { CRISIS }_{i}+e_{i} \\
& G C M=\beta_{0}+\beta_{1} A C \_I N E D_{i}+\beta_{2} E_{\text {EXERT }}+\beta_{3} \text { FEERATIO }_{i}+\beta_{4}{\text { FEERATIO } * A C \_N E D_{i}+}+ \\
& \beta_{5} \text { FEERATIO*AC_INED }{ }_{i}+\beta_{6} \text { FEERATIO*EXPERT } T_{i} \beta_{7} A C \_S I Z_{i}+ \\
& \beta_{8} \text { REPORTLAG } i+\beta_{9} \text { TENURE }_{i}+\beta_{10} \text { BIGN }_{i}+\beta_{11} L n C O M \_S I Z_{i}+\beta_{12} \mathrm{COMPLEX}_{i}+ \\
& \beta_{13} \mathrm{LOSS}_{i}+\beta_{14} \mathrm{LEV}_{i}+\beta_{15} \mathrm{PRIOR}_{i}+\beta_{16} \mathrm{CRISIS}_{i}+e_{i}
\end{aligned}
$$


where,

GCM

AC_INED

EXPERT
FEERATIO

= going-concern modification measured as a dummy variable, coded 1 if a modified going-concern opinion is issued, 0 otherwise. The modified going-concern opinions include qualified opinions, adverse opinions, disclaimers for going-concern issues, and unqualified opinions with an emphasis of matter paragraph highlighting the presence of going-concern uncertainty;

= percentage of audit committee members who are independent NEDs;

= percentage of financial experts on the audit committee;

$=$ the ratio of total auditor-provided NAS fees to audit services fees;

FEERATIO*AC_NED = interaction term between the ratio of total auditor-provided NAS fees to audit services fees and the percentage of audit committee members who are NEDs;

FEERATIO*AC_INED = interaction term between the ratio of total auditor-provided NAS fees to audit services fees and the percentage of audit committee members who are independent NEDs;

FEERATIO*EXPERT = interaction term between the ratio of total auditor-provided NAS fees to audit services fees and the percentage of financial experts on the audit committee;

AC_SIZ

REPORTLAG

= audit committee size: number of audit committee members;

$=$ number of days between the year end and the audit report date;

TENURE

BIGN

LnCOM_SIZ

= length of auditor-client relationship in years;

= dummy variable with a value of 1 if the company was audited by a Big 4/or 5 audit firm, 0 otherwise;

$=$ natural log of total assets (proxy for firm size);

= percentage of foreign subsidiaries in total subsidiaries;

= a dummy variable with a value of 1 if the company reported negative net income for the fiscal year, 0 otherwise;

$\mathrm{LEV} \quad=$ the ratio of total debt to total assets;

PRIOR

CRISIS

$\beta$

$e_{\mathrm{i}}$
$=$ dummy variable with a value of 1 if the company received a going-concern modification in the preceding year, 0 otherwise; $=$ a dummy variable with a value of 1 if the last audit opinion date prior to failure was after 31 December 2007, 0 otherwise;

= parameters;

= error term; and 
For independent variables, we measure audit committee independence by the percentage of NEDs (AC_INED) on the audit committee who are independent. Independent NEDs are defined as NEDs with no financial or personal ties to the company or its management, as per the UK Corporate Governance Code (2012). ${ }^{12}$ We measure an audit committee’s competence in accounting and/or audit by the percentage of financial experts on the audit committee. ${ }^{13}$ Financial expertise is important for the effectiveness of an audit committee because this committee is responsible for numerous duties that require a relatively high degree of accounting/audit sophistication in monitoring the financial reporting process (DeFond et al., 2005). ${ }^{14}$ We use the ratio of auditor-provided NAS fees to audit services fees paid to the auditor (FEERATIO) to represent the relative use of auditor-provided NAS, and to capture regulatory concern over the possibility that auditors may lowball audit clients and recoup audit fee cuts through the provision of NAS (Firth, 1997; Smith Report, 2003).

The interaction term between the ratio of auditor-provided NAS fees to audit services fees and the percentage of independent NEDs on the audit committee (FEERATIO*AC_INED) is introduced to capture the effect of auditor-provided NAS fees on the likelihood of receiving a

\footnotetext{
12 The UK Corporate Governance Code (2012) sets precise criteria for independence on the basis of whether a director: (a) has been an employee of the company or group within the last five years; (b) has or had in the last three years a material business relationship with the company; (c) has received additional remuneration such as a performance-related payment and pension from the company apart from a director's fee; (d) has close family ties with the company's other directors, advisors, or senior employees; (e) holds cross-directorships; (f) represents a significant shareholder; or (g) has served on the board for more than nine years.

${ }_{13}$ Financial expertise is demonstrated by membership of a professional accounting and/or financial body or previous or current employment in accounting or finance (see Smith Report, 2003).

14 The main role and responsibilities of the audit committee are set out in Provision C3.2 of the UK Corporate Governance Code (2012) and Financial Services Authority, FSA, Disclosure and Transparency Rules 7.1.
} 
going-concern modification when audit committee independence increases. The interaction term between the ratio of auditor-provided NAS fees to audit services fees and the percentage of financial experts on the audit committee (FEERATIO*EXPERT) is introduced to capture the effect of auditor-provided NAS fees on the likelihood of receiving a going-concern modification when the proportion of financial experts on the audit committee increases.

The control variables are drawn from the literature. First, audit committee size (AC_SIZ) is used to control for audit committee power (Kalbers \& Fogarty, 1993). Larger audit committees are more likely to behave as authoritative bodies exercising effective monitoring functions (Archambcault \& DeZoort, 2001). Therefore, it is expected that there is a positive relationship between audit committee size and audit quality.

Second, the time between the fiscal year-end and the audit report date (REPORTLAG) is included in the model to control for the timeliness of audit opinions. Prior research suggests that auditors may spend a longer time auditing troubled firms. It is found that companies receiving going-concern modification have longer reporting lags (DeFond et al., 2002).

Third, auditor tenure (TENURE) is employed to control for the auditor-client relationship. Empirical evidence on the association between auditor tenure and financial reporting quality is mixed. It is suggested that auditors who have long served a particular client are more likely to possess client-specific knowledge and increase audit quality. Long tenure may, however, 
increase the closeness of the auditor-client relationship and thus impair auditor independence (Johnson, Khurana, \& Reynolds, 2002; Ghosh \& Moon, 2005).

Fourth, the presence of a Big 4/5 auditor (BIGN) is used to control for opinion-decision differences between the Big 4/5 and non-Big 4/5 audit firms. Prior literature suggests that large audit firms are more likely to issue a going-concern modification because they have more expertise and resources that allow them to exhibit better audit quality (Geiger \& Rama, 2006). In addition, the larger audit firms face higher reputation loss and litigation risk, which would lead to them being relatively more conservative in their reporting decisions compared to the smaller audit firms (Mutchler et al., 1997).

Fifth, the natural log of total assets (LnCOM_SIZ) is used to control for firm size. Large companies may be less likely to fail. Studies have suggested that a larger client has a stronger negotiating power with its auditors. Auditors are reluctant to issue a going-concern modification to a large client due to the risk of losing the client's significant business (Mutchler et al., 1997; Carcello \& Neal, 2000).

Sixth, we also include the percentage of foreign subsidiaries (COMPLEX) to capture business complexity. It is suggested that complex firms are more likely to receive modified audit opinions because higher business complexity could lead to more reporting errors and irregularities (Craswell et al., 2002). 
Seventh, the presence of a prior year going-concern modification (PRIOR) is used as a control variable, since it has been suggested that firms that receive going-concern modifications in the current year are more likely to receive them in the subsequent year (Mutchler, 1985; Nogler, 1985).

Finally, we control for the effect of the financial crisis in 2007 (CRISIS) on auditor reporting decisions. Auditors' decisions are likely to have been more conservative in the period after the financial crisis because of higher intensive legislative and media scrutiny (The Sharman Inquiry, 2012). It is therefore expected that auditors are more likely to issue a going-concern modification after the financial crisis.

\section{Results}

4.1 Descriptive statistics and univariate analysis

Of the failed firms, 39 received modified going-concern opinions for the last financial reports issued prior to failure, while 77 did not receive such opinions, suggesting that only $34 \%$ of the failed firms received a going-concern modification preceding failure. This result is consistent with the finding of Citron and Taffler (1992), reporting that a large majority of the failed firms in the UK did not receive an auditor's going-concern modification.

Table 2 presents descriptive statistics for failed firms receiving a modified going-concern opinion prior to failure compared to failed firms receiving a non-modified (clean) opinion 
and provides the results of the t-test and the Wilcoxon rank sum test for the continuous variables and the Chi-squared test for categorical variables. Among firms receiving going-concern modifications, on average, $76.50 \%$ of their audit committee members are independent NEDs (AC_INED). By contrast, only 64.63\% of audit committee members are independent NEDs for firms receiving clean opinions. The difference is significant at the 5\% level (T-test). This finding supports Hypothesis 1, which states that there is a positive association between the proportion of independent directors on the audit committee and the likelihood of receiving a going-concern modification prior to failure.

In addition, the mean percentages of financial experts on the audit committee (EXPERT) for the failed firms receiving a going-concern modification and firms receiving a clean opinion are $50.00 \%$ and $30.02 \%$, respectively, and this difference is statistically significant at the $1 \%$ level. The finding thus supports Hypothesis 2, i.e., the proportion of financial experts on the audit committee is positively related to the likelihood of receiving going-concern modifications prior to failure. Moreover, the result indicates that, on average, both groups of firms (i.e. the groups receiving modified and clean audit opinions) pay relatively more NAS fees than audit fees to their auditors. The mean values of the ratios of NAS fees to audit services fees (FEERATIO) for the failed firms that receive a going-concern modification and that receive a clean opinion are 1.72 and 1.87, respectively. This difference, however, is not statistically significant. The finding does not support Hypothesis 3, which states a positive 
association between auditor-provided NAS fees and the likelihood of going-concern modification prior to failure.

Regarding the control variables, the average audit committee size (AC_SIZ) values are 2.62 and 2.83 for the failed firms receiving a going-concern modification and a clean opinion, respectively, and this difference is not statistically significant. In line with prior literature (e.g., DeFond et al., 2002), it is found that the companies receiving a going-concern modification, compared to those receiving a clean opinion, have a longer time lag between the fiscal year-end and the audit report date (REPORTLAG). In addition, there is no significant difference in both auditor tenure (TENURE) and audit firm size (BIGN) between the firms receiving a going-concern modification and a clean opinion.

It appears that firms with larger size (COM_SIZ) are less likely to receive a going-concern modification prior to failure, but firm complexity (COMPLEX) is not significantly related to the likelihood of receiving a going-concern modification. Consistent with expectations, the firms with a loss (LOSS) and higher leverage level (LEV) are more likely to receive a going-concern modification prior to failure. Moreover, firms receiving a going-concern modification in the prior year (PRIOR) are more likely to receive a modified opinion in the report prior to failure. An auditor's propensity to issue a going-concern modification is not significantly related to the financial crisis (CRISIS). 
Insert Table 2 about here

\subsection{Logistic regression analysis}

Because multicollinearity is considered as problematic in regression analysis, the Spearman rho correlations between variables are provided in Table 3, and the variance inflation factors (VIFs) are computed for each independent variable to examine whether multicollinearity is present. The correlations between independent variables included in the regression analysis are all less than 0.38 . Multicollinearity in regression analysis is regarded as harmful only when correlations exceed 0.7 (Tabachnick \& Fidell, 2007). In addition, the VIFs are below 2.1 for all independent variables employed in the regressions shown in Tables 4 and 5, far lower than the critical value of 10 (Tabachnick \& Fidell, 2007): this suggests that multicollinearity is not a major issue in the regression analyses. We also employ the link test to examine whether the logistic model is properly specified, and find that there is no significant specification error for the models shown in Tables 4 and 5. 
Insert Table 3 about here

Table 4 presents results of the logistic regression models used to examine the relationships between audit committee characteristics, the ratio of auditor-provided NAS fees to audit services fees, and the likelihood of auditor going-concern modifications prior to failure. The overall models are significant, and the model Pseudo $\mathrm{R}^{2}$ is above 0.3425 . The overall classification rates for the models are above $81.03 \%$. Firstly, We examine the effect of independent NEDs on the audit committee on the auditor's going-concern reporting decisions and reveal that the higher the percentage of independent NEDs on the audit committee (AC_INED) the more likely the auditor is to issue a going-concern modification prior to failure $(p<0.05)$. This suggests that an audit committee composed of more independent NEDs is more capable of safeguarding high audit reporting quality in the context of prior corporate failure. This finding is in line with the agency perspective and lends support to regulators' emphasis on the importance of audit committee independence for reporting quality (e.g., Smith Report, 2003; UK Corporate Governance Code, 2012). 
In addition, we investigate the relationship between the percentage of financial experts on the audit committee (EXPERT) and the auditor's going-concern reporting decisions. The likelihood of receiving an auditor going-concern modification prior to failure is positively associated with the proportion of financial experts on the audit committee. This is consistent with the suggestion of DeZoort and Salterio (2001) and Hypothesis 2, and implies that more financial experts on the audit committee could improve auditor reporting quality. In line with some prior studies (e.g., DeFond et al., 2002), however, the ratio of auditor-provided NAS fees to audit services fees (FEERATIO) is not significantly related to the likelihood of a going-concern modification. This result does not support Hypothesis 3 that auditor-provided NAS impairs auditor reporting quality.

With regard to the control variables, similar to the results generated from the univariate analysis, the time lag between the fiscal year-end and the audit report date (REPORTLAG) is positively related to the likelihood of an auditor going-concern modification prior to failure. In addition, firms that had a loss (LOSS) ${ }^{15}$ and received a going-concern modification in the prior year (PRIOR) are more likely to receive a going-concern modification in the report preceding failure. There is a weak positive relationship between a firm’s leverage level (LEV) and the likelihood of receiving a going-concern modification. However, the variables of audit committee size (AC_SIZ), auditor tenure (TENURE), audit firm size (BIGN), company size

\footnotetext{
15 We also use return on assets as a proxy for a firm's profitability. The results show that there is no significant relationship between return on assets and the likelihood of going-concern modifications, and the significance of the other variables substantively similar to that reported in the paper.
} 
(LnCOM_SIZ), firm complexity (COMPLEX) and financial crisis (CRISIS) are not significantly associated with the likelihood of an auditor going-concern modification prior to failure.

Insert Table 4 about here

We further analyze whether audit committee independence and financial expertise has mediated the relationship between auditor reporting decisions prior to failure and auditor-provided NAS fees. To test the mediating effects of audit committee characteristics on the likelihood of an auditor going-concern modification, we introduce interaction terms between the percentages of independent NEDs (AC_INED) and financial experts (EXPERT) on the audit committee, and the ratio of auditor-provided NAS fees to audit services fees (FEERATIO). To avoid multicollinearity between the interaction terms and their constituent variables, we mean-centre AC_INED and EXPERT, and FEERATIO before adding them to the regression models (see Vallascas \& Hagendorff, 2013). 
Table 5 sets forth the results for the interactive effects of the audit committee characteristics and FEERATIO on the likelihood of auditors issuing a going-concern modification. Panel A of Table 5 reports the logistic results for the effects of the interaction terms between the ratio of auditor-provided NAS fees to audit services fees and the percentage of independent NEDs on the audit committee (FEERATIO*AC_INED) (Model (1)), and the percentage of financial experts on the audit committee (FEERATIO*EXPERT) (Model (2)). Significantly positive coefficients on those interactions indicate that increases in the ratio of auditor-provided NAS fees to audit services fees (FEERATIO) are associated with the higher likelihood of an auditor going-concern modification as the percentages of independent NEDs (AC_INED) and financial experts (EXPERT) on the audit committee increase.

Panel B of Table 5 further reports how the impact of FEERATIO on the likelihood of an auditor going-concern modification varies with different values of the audit committee characteristics. The results demonstrate that FEERATIO is negatively associated with the likelihood of an auditor going-concern modification as there are $50 \%$ and $66.67 \%$ of independent NEDs on the audit committee (i.e. at the $25 \%$ and $50 \%$ percentiles of the sample distribution of AC_INED, respectively). By contrast, there is no significant association between FEERATIO and the likelihood of an auditor going-concern modification when the audit committee is fully composed of independent NEDs (i.e. at the $75 \%$ percentile of the 
sample distribution of AC_INED). The findings suggest that the presence of a highly independent audit committee may moderate the potential threat posed by NAS to audit reporting quality.

In addition, it is found that FEERATIO is negatively related to the likelihood of an auditor going-concern modification when there is no financial expert and when the proportion of members of the audit committee who are financial experts is at $33.33 \%$ (i.e. at the $25 \%$ and $50 \%$ percentiles of the sample distribution of EXPERT, respectively). The relationship between the percentage of financial experts on the audit committee and the likelihood of a going-concern modification becomes insignificant when the proportion of members on the audit committee who are financial experts reaches $50 \%$ (i.e. at the $75 \%$ percentile of the sample distribution of EXPERT). The result also reflects the importance of the financial expertise of the audit committee in mitigating the potential negative effect of NAS on auditor reporting quality. Overall, the findings are consistent with Hypothesis 4 that the relation between the likelihood of an auditor going-concern modification and auditor-provided NAS is subject to audit committee characteristics, implying that the purchase of NAS is less likely to result in an unfavorable impact on auditors' going-concern reporting decisions prior to failure when the failed firms have a more independent audit committee or has a more financially expert committee. 
Insert Table 5 about here

\subsection{Further analysis}

To ensure rigorous results, we conduct several additional tests. Because the UK Corporate Governance Code (2012) recommends that an audit committee should be composed entirely of independent NEDs and a minimum of one financial expert to enhance its monitoring function, we replaced the variables of the percentages of independent NEDs and financial experts on the audit committee used in the logistic regression (shown in Table 4) with two dichotomous variables to capture the effects of the presence of a fully independent audit committee and the presence of financial expertise on the audit committee. We give a value of 1 to both variables if the company has an audit committee composed entirely of independent non-executive directors or has at least one financial expert on its audit committee and 0 otherwise. The results for the presence of a fully independent audit committee and the 
presence of financial expertise on the audit committee indicate the same direction as the main findings reported in Table 4 and remain significant at the 5\% and 10\% levels, respectively.

Further, we estimate the combined effects of the presence of a fully independent audit committee, the presence of financial expertise on the audit committee, and the ratio of auditor-provided NAS fees to audit services fees (FEERATIO) on the likelihood of going-concern modifications. Consistent with the main findings reported in Panel A of Table 5, the interaction terms between FEERATIO and the presence of a fully independent audit committee and between FEERATIO and the presence of financial expertise on the audit committee are positively related to the likelihood of an auditor going-concern modification. Additionally, in line with the findings presented in Panel B of Table 5, the results for the marginal effects show that there is a negative relationship between FEERATIO and the likelihood of an auditor going-concern modification when the audit committee is not composed entirely of independent NEDs or does not have at least one financial expert. By contrast, this relationship is not significant in the firms with an audit committee entirely composed of independent NEDs or with financial expertise on the audit committee.

Some prior studies indicate that there is a substantial incentive for audit firms to act more favorably toward those audit clients that pay them a higher magnitude of NAS fees. If auditors receive lucrative NAS fees from a single audit client, they are more likely to provide a clean opinion to preserve their interests with respect to NAS (DeFond et al., 2002; 
Basioudis et al., 2008). We replace the variable of the ratio of auditor-provided NAS fees to audit services fees (FEERATIO) employed in Table 4 with the natural log of auditor-provided NAS fees. The result shows that the natural log of auditor-provided NAS fees is also not significantly related to the likelihood of a going-concern modification.

Then, we examine the combined effects of audit committee characteristics and the natural log of auditor-provided NAS fees on the likelihood of auditor going-concern modification. Consistent with our main findings shown in Table 5, the interaction terms between the percentages of independent NEDs on the audit committee, the percentage of financial experts on the audit committee, and the natural log of auditor-provided NAS fees are positively associated with the likelihood of a going-concern modification. Further, we also find that the relationship between the natural log of auditor-provided NAS fees and auditor reporting decisions varies in terms of the independence and financial expertise of the audit committee. The natural log of auditor-provided NAS fees has a significant positive association with the likelihood of auditor going-concern modification when the percentages of independent NEDs and financial experts on the audit committee are low (i.e. at the $25 \%$ percentile of the sample distribution of AC_INED and EXPERT). Those associations become insignificant when the independence and financial expertise of the audit committee are higher (i.e. at both the $50 \%$ and $75 \%$ percentiles of the sample distribution of AC_INED and EXPERT). Those results appear to be consistent with the reported findings in the main tests. 
With regard to the control variables, we employ the variables of auditor switch and Z-score to replace TENURE and LOSS, respectively, shown in Tables 4 and 5. The presence of auditor switch is employed to control for audit opinion shopping. Prior literature argues that audit clients may shop around auditors looking for more favourable audit opinions (Craswell et al., 2002). We therefore expect the presence of an auditor switch to be negatively related to the likelihood of an auditor going-concern opinion. We give a value of 1 if the company switched its auditor up to three years prior to the year studied, and 0 otherwise. The Z-score is the probability-of-bankruptcy score developed by Taffler (1984), with a lower value indicating a higher probability of corporate failure (Agarwal \& Taffler, 2007). It is expected that a firm with lower Z-score is more likely to receive an auditor going-concern opinion. The results show that the likelihood of going-concern modifications is not significantly related to the presence of auditor switch and Z-score. The significance of the other variables is substantively similar to the primary results reported in Tables 4 and 5 .

It is suggested that auditors may encounter higher pressure from the clients' managers in the process of issuing a first-time going-concern opinion (Blay \& Geiger, 2013). There were 15 sample companies (13\% of the total observations) which received a going-concern modification in the preceding year. We delete those observations and the variable, PRIOR, from the models, and re-run the analyses. The results of the models are essentially identical to those presented. In addition, since our sample period spans 13 years, the empirical results 
may be driven by any particular year within the sample period (Geiger \& Rama, 2006). Thus, we remove observations in each of our sample years and separately perform the analyses. Eliminating observations on a yearly basis for the respective sets of analyses produce results substantively the same as those reported.

Finally, we re-perform the tests by using probit analysis. The results are essentially the same as those based on the logistic analysis presented in Tables 4 and $5 .{ }^{16}$ Overall, the results of the additional tests reinforce the importance of the audit committee with respect to auditor reporting quality and confirm the moderating effects of its independence and financial expertise on the threat posed by NAS.

\section{Conclusions}

The recent invigorated debate over auditor reporting quality prior to corporate failure has often made reference to corporate governance structure and auditor-provided NAS fees. To address the concerns, corporate governance reformers have considered the audit committee as having a central role. The audit committee is charged to review and monitor the external auditor's independence and objectivity, the effectiveness of the audit process and the value of auditor-provided NAS. According to the agency perspective, an audit committee with more independent directors and financial experts will work more effectively as members with such

\footnotetext{
${ }^{16}$ We perform the lagrange multiplier test for the normality of the residuals of a probit model. The normality hypothesis of the residuals is not rejected in our probit models.
} 
characteristics have the incentives and are more capable of overseeing the audit process and the purchase of auditor-provided NAS.

The present research provides new evidence on whether the issuing by auditors of a standard unmodified opinion for companies subsequently failing is related to the independence and financial expertise of the audit committee and auditor provision of NAS. Specifically, we examined whether the threat posed by NAS to auditor reporting quality is mediated by the independence and financial expertise of the audit committee.

In line with prior studies, only $34 \%$ of UK failed companies in our sample received going-concern modifications immediately prior to failure. The empirical results generated from univariate and logistic analyses suggest that the percentages of independent NEDs and financial experts on the audit committee are positively related to the likelihood of an auditor going-concern modification. However, there is no significant association between auditor-provided NAS fees and the likelihood of an auditor going-concern modification. We further find that the effect of auditor-provided NAS on auditor reporting decisions is mediated by the audit committee characteristics. The interaction terms between auditor-provided NAS fees and the percentages of independent NEDs and financial experts on the audit committee are positively related to the likelihood of a going-concern modification. Auditor-provided NAS are less likely to be associated with the issuance of a 
standard unmodified opinion prior to failure when the audit committee is composed of more independent NEDs and financial experts, which is consistent with the agency perspective.

The findings of this study suggest implications for the corporate governance literature and corporate governance policy. Overall, the findings support the logic of the agency perspective in this domain and corporate governance regulators' concerns about the importance of the independence and financial expertise of an audit committee. Specifically, this study provides evidence that the link between the provision of NAS and auditor reporting quality is mediated by the independence and financial expertise of the audit committee, suggesting the importance of audit committee characteristics in relation to a company's decisions on purchasing NAS.

Although the results of this research are important, they must be interpreted in the light of the following limitations. First, as in the case of earlier relevant research studying the setting of corporate failure, the number of observations employed in our empirical analysis is relatively small. ${ }^{17}$ However, the sample selection procedures captured all the relevant firms with respect to the research questions in that this research investigates the entire population of the UK non-financial failed firms with an audit committee between 1997 and 2010. Thus, the possible limitation in relation to the size of observation would be minimal in this setting (see

${ }^{17}$ As we noted earlier, we find in our UK-based study that relatively few large-scale companies have been subject to failure, consistent with the prior relevant study by Citron and Taffler (1992) that employed 107 failed companies between 1977-1986. Similarly, there were 89,134,134 and 92 failed companies in the relevant U.S. studies by Menon and Schwartz (1987), McKeown et al. (1991), Hopwood et al. (1994) and Callaghan et al. (2009), respectively. 
Sharma \& Sidhu, 2001; Callaghan, Parkash, \& Singhal, 2009). Second, due to availability of data, this research focuses only on the structural characteristics of the audit committee. Further studies can adopt survey or in-depth interview to explore how an audit committee interacts with both auditors and management to enhance understanding of the effectiveness of the audit committee in terms of auditor reporting quality. Third, it is important to realise that all NAS fees are paid for particular services rendered. The Smith Report (2003) suggests that whether the provision of NAS is a threat to auditor independence depends on the nature of each particular case. However, further identification of different types of NAS is limited by the respective procedures for public filing adopted by each company, which may be taken as a criticism of those procedures. Future research could usefully explore the relationships identified in this study in greater depth through more detailed classification of NAS. 


\section{Reference:}

Abbott, L. J., Parker, S., \& Peters, G. (2004). Audit committee characteristics and restatements. Auditing: A Journal of Practice and Theory, 23, 69-87.

Abbott, L. J., Parker, S., Peters, G., \& Raghunandan, K. (2003). An empirical investigation of audit fees, nonaudit fees and audit committees. Contemporary Accounting Research, 20, 215-234.

Agarwal, V., \& Taffler, R. J. (2007). Twenty-five years of the Taffler z-score model: Does it really have predictive ability? Accounting and Business Research, 37, 285-300.

Antle, R., \& Nalebuff, B. (1991). Conservatism and auditor-client negotiations. Journal of Accounting Research, 29, 31-54.

Archambcault, D., \& DeZoort, F. T. (2001). Auditor opinion shopping and the audit committee: An analysis of suspicious auditor switches. International Journal of Auditing, 5, 33-52.

Arcot, S., Bruno, V., \& Faure-Grimaud, A. (2010). Corporate governance in the UK: Is the comply or explain approach working? International Review of Law and Economics, 30, 193-201.

Auditing Practices Board. (2011). APB Ethical Standard 5 (Revised): Non-audit services provided to audited entities. London: APB.

Auditing Practices Board. (2012). ISA (UK and Ireland) 705: Modifications to opinions in the independent auditor's report. London: APB.

Auditing Practices Board. (2014). ISA (UK and Ireland) 570: Going concern. London: APB.

Bédard, J., Chtourou, S. M., \& Courteau, L. (2004). The effects of audit committee expertise, independence and activity on aggressive earnings management. Auditing: A Journal of Practice and Theory, 23, 13-35.

Basioudis, I. G., Papakonstantinou, E., \& Geiger, M. A. (2008). Audit fees, non-audit fees and auditor going-concern reporting decisions in the United Kingdom. Abacus, 44, 284-309.

Beasley, M., Carcello, J., Hermanson, D., \& Neal, T. (2009). The audit committee oversight process. Contemporary Accounting Research, 26, 65-122.

Blay, A., \& Geiger, M. A. (2013). Auditor fees and auditor independence: Evidence from going concern reporting decisions. Contemporary Accounting Research, 30, 579-606.

Blue Ribbon Committee. (1999). Report and recommendations of the Blue Ribbon Committee on improving the effectiveness of corporate audit committees. New York: New York Stock Exchange.

Cadbury, A. (1992). Report of the committee on the financial aspects of corporate governance. London: Gee.

Callaghan, J., Parkash, M., \& Singhal, R. (2009). Going-concern audit opinions and the 
provision of nonaudit services: Implications for auditor independence of bankrupt firms. Auditing: A Journal of Practice and Theory, 28, 153-169.

Carcello, J., \& Neal, T. (2000). Audit committee composition and auditor reporting. The Accounting Review, 75, 453-467.

Carcello, J., \& Neal, T. (2003). Audit committee characteristics and auditor dismissals following "new" going-concern reports. The Accounting Review, 78, 95-117.

Citron, D., \& Taffler, R. (1992). The audit report under going concern uncertainties: An empirical analysis. Accounting and Business Research, 22, 337-345.

Citron, D., Taffler, R., \& Uang, J. (2008) Delays in reporting price-sensitive information:

The case of going concern. Journal of Accounting and Public Policy, 27, 19-37.

Collier, P., \& Gregory, A. (1996). Audit committee effectiveness and the audit fee. European Accounting Review, 5, 177-198.

Combined Code. (2003). The combined code on corporate governance. London: FRC.

Craswell, A. T., Stokes, D. J., \& Laughton, J. (2002). Auditor independence and fee dependence. Journal of Accounting and Economics, 33, 253-275.

DeAngelo, L. E. (1981). Auditor independence,"low balling", and disclosure regulation. Journal of Accounting and Economics, 3, 113-127.

DeFond, M. L., Hann, R. N., \& Hu, X. (2005). Does the market value financial expertise on audit committees of boards of directors? Journal of Accounting Research, 43, 153-193.

DeFond, M. L., Raghunandan, K., \& Subramanyam, K. R. (2002). Do non-audit service fees impair auditor independence? Evidence from going concern audit opinions. Journal of Accounting Research, 40, 1247-1274.

DeZoort, F. T., \& Salterio, S. E. (2001). The effect of corporate governance experience and financial reporting and audit knowledge on audit committee members' judgements. Auditing: A Journal of Practice and Theory, 20, 31-47.

Dhaliwal, D., Naiker, V., \& Navissi, F. (2010). The association between accruals quality and the characteristics of accounting experts and mix of expertise on audit committees. Contemporary Accounting Research, 27, 787-827.

Fama, E. F. (1980). Agency problems and the theory of the firm. Journal of Political Economy, 88, 134-145.

Fama, E. F., \& Jensen, M. C. (1983). Separation of ownership and control. Journal of Law and Economics, 26, 301-325.

Feldmann, D. A., \& Read, W. J. (2010). Auditor conservatism after Enron. Auditing: A Journal of Practice \& Theory, 29, 267-278.

Ferguson, A., Seow, G., \& Young, D. (2004). Nonaudit services and earnings management: UK evidence. Contemporary Accounting Research, 21, 813-841.

Firth, M. (1980). A note on the impact of audit qualifications on lending and credit decisions. 
Journal of Banking and Finance, 4, 257-267.

Firth, M. (1997). The provision of nonaudit services by accounting firms to their audit clients. Contemporary Accounting Research, 14, 1-21.

Gaynor, L., McDaniel, L., \& Neal, T. (2006). The effects of joint provision and disclosure of nonaudit services on audit committee members' decisions and investors' preferences. The Accounting Review, 81, 873-896.

Geiger, M. A., \& Rama, D. V. (2006). Audit firm size and going-concern reporting accuracy. Accounting Horizons, 20, 1-17.

Ghafran, C. M., \& O'Sullivan, N. (2012). The governance role of audit committee: Reviewing a decade of evidence. International Journal of Management Reviews, 15, 381-407.

Ghosh, A., \& Moon, D. (2005). Does auditor tenure impair audit quality? The Accounting Review, 80, 585-612.

Habib, A. (2012). Non-audit service fees and financial reporting quality: A meta-analysis. Abacus, 48, 214-248.

House of Lords. (2011). Auditors: Market concentration and their role. Select committee on economic affairs. 2nd report of session 2010-2011. London: The Stationery Office Limited.

Hudaib, M., \& Cooke, T. E. (2005). The impact of managing director changes and financial distress on audit qualification and auditor switching. Journal of Business Finance and Accounting, 39, 1703-1739.

Jensen, M. C., \& Meckling, W. H. (1976). Theory of the firm: managerial behaviour, agency costs and ownership structure. Journal of Financial Economics, 13, 305-360.

Johnson, V. E., Khurana, I. K., \& Reynolds, J. K. (2002). Audit-firm tenure and the quality of financial reports. Contemporary Accounting Research, 19, 637-660.

Kalbers, L. P., \& Fogarty, T. J. (1993). Audit committee effectiveness: an empirical investigation of the contribution of power. Auditing: A Journal of Practice and Theory, 12, 24-49.

Khurana, I. K., \& Raman, K. K. (2004). Litigation risk and the financial reporting credibility of Big 4 versus non-Big 4 audits: Evidence from Anglo-American Countries. The Accounting Review, 79, 473-495.

Kida, T. (1980). An investigation into auditors' continuity and related qualification judgments. Journal of Accounting Research, Autumn, 506-523.

Klein, A. (2002). Audit committee, board of director characteristics, and earnings management. Journal of Accounting and Economics, 33, 375-400.

Koh, H. (1991). Model predictions and auditor assessment of going concern status. Accounting and Business Research, 21, 331-338.

Krishnan, G. V., \& Visvanathan, G. (2010). Does the SOX definition of an accounting expert 
matter? The association between audit committee directors' accounting expertise and accounting conservatism. Contemporary Accounting Research, 25, 827-858.

Krishnan, J. (2005). Audit committee quality and internal control: an empirical analysis. The Accounting Review, 80, 649-675.

Lennox, C. S. (1999). Non-audit fees, disclosure and audit quality. European Accounting Review, 8, 239-252.

Levitan, A. S., \& Knoblett, J. A. (1985). Indicators of exceptions to the going concern assumption. Auditing: A Journal of Practice and Theory, 5, 26-39.

Li, J., Mangena, M., \& Pike, R. (2012). The effect of audit committee characteristics on intellectual capital disclosure. The British Accounting Review, 44, 98-110.

Mangena, M., \& Pike, R. (2005). The effect of audit committee shareholding, financial expertise and size on interim financial disclosures. Accounting and Business Research, 35, 327-349.

McKeown, J. C., Mutchler, J. F., \& Hopwood, W. (1991). Towards an explanation of auditor failure to modify the audit opinions of bankrupt companies. Auditing: A Journal of Practice and Theory, 10, 1-13.

Menon, K., \& Williams, D. (2010). Investor reaction to going concern audit reports. The Accounting Review, 85, 2075-2105.

Mutchler, J. F. (1985). A multivariate analysis of the auditor's going-concern opinion decision. Journal of Accounting Research, 23, 668-682.

Mutchler, J. F., Hopwood, W., \& McKeown, J. C. (1997). The influence of contrary information and mitigating factors on audit opinion decisions on bankrupt companies. Journal of Accounting Research, 35, 295-310.

Neophytou, E., \& Molinero, C. M. (2004). Predicting corporate failure in the UK: A multidimensional scaling approach. Journal of Business Finance \& Accounting, 31, 677-710.

Nogler, G. E. (1985). The resolution of auditor going concern opinions. Auditing: A Journal of Practice and Theory, 14, 54-73.

O'Sullivan, N. (2000). The impact of board composition and ownership on audit quality: Evidence from large UK companies. The British Accounting Review, 32, 397-414.

Palmrose, Z. V. (1986). Audit fees and auditor size: Further evidence. Journal of Accounting Research, 24, 97-110.

Patton, A., \& Baker, J. C. (1987). Why won't directors rock the boat? Harvard Business Review, 65, 10-18.

Peel, M. J., \& Peel, D. A. (1988). A multilogit approach to predicting corporate failure - some evidence for the UK corporate sector. OMEGA: International Journal of Management Science, 16, 309-318.

Pomeroy, B., \& Thornton, D. B. (2008). Meta-analysis and the accounting literature: The 
case of audit committee independence and financial reporting quality. European Accounting Review, 17, 305-330.

Ruddock, C., Taylor, S. J., \& Taylor, S. L. (2006). Nonaudit services and earnings conservatism: Is auditor independence impaired? Contemporary Accounting Research, 23, 701-746.

Ruiz-Barbadillo, E., Gomez-Aguilar, N., Fuentes-Barbera, C. D., \& Garcia-Benau, M. A. (2004). Audit quality and the going-concern decision-making process: Spanish evidence. European Accounting Review, 13, 597-620.

Seetharaman, A., Gul, F. A., \& Lynn, S. G. (2002). Litigation risk and audit fees: Evidence from UK firms cross-listed on US markets. Journal of Accounting and Economics, 33, 91-115.

Sharma, D. S., \& Sidhu, J. (2001). Professionalism vs commercialism: The association between non-audit services and audit independence. Journal of Business, Finance and Accounting, 25, 595-629.

Simunic, D. A. (1984). Auditing, consulting, and auditor independence. Journal of Accounting Research, 22, 679-702.

Smith Report. (2003). Audit committees combined code guidance. A report and proposed guidance by the FRC. London: FRC.

Tabachnick, B. G., \& Fidell, L. S. (2007). Using multivariate statistics. London: Pearson/Allyn \& Bacon.

Taffler, R. J. (1984). Empirical models for the monitoring of UK corporation. Journal of Banking and Finance, 8, 199-227.

Teoh, S. H. (1992). Auditor independence, dismissal threats, and the market reaction to auditor switches. Journal of Accounting Research, 30, 1-23.

The Sharman Inquiry. (2012). Going concern and liquidity risks: Lessons for companies and auditors. Final Report and Recommendations of the Panel of Inquiry. London: UKSA.

UK Corporate Governance Code. (2012). The UK corporate governance code. London: FRC.

Vallascas, F., \& Hagendorff, J. (2013). The risk sensitivity of capital requirements: Evidence from an international sample of large banks. Review of Finance, 17, 1947-1988.

Zaman, M., Hudaib, M., \& Haniffa, R. (2011). Corporate governance quality, audit fees and non-audit services fees. Journal of Business Finance and Accounting, 38, 165-197. 
Table 1

The Characteristics of Failed Sample Firms

\begin{tabular}{|c|c|c|c|c|c|}
\hline \multicolumn{3}{|c|}{ Panel A: Number of the sample companies } & \multicolumn{3}{|c|}{$\begin{array}{l}\text { Panel B: Distribution of the FTSE industrial classification of } \\
\text { the sample companies }\end{array}$} \\
\hline $\begin{array}{c}\text { Delisting } \\
\text { year }\end{array}$ & Frequency & Percentage & Industrial Classifications & Frequency & Percentage \\
\hline 1997 & 4 & $3 \%$ & Basic Materials & 8 & $7 \%$ \\
\hline 1998 & 7 & $6 \%$ & Industrials & 30 & $26 \%$ \\
\hline 1999 & 11 & $10 \%$ & Consumer Goods & 21 & $18 \%$ \\
\hline 2000 & 11 & $10 \%$ & Health Care & 6 & $5 \%$ \\
\hline 2001 & 15 & $13 \%$ & Consumer Services & 27 & $23 \%$ \\
\hline 2002 & 22 & $19 \%$ & Telecommunications & 6 & $5 \%$ \\
\hline 2003 & 11 & $10 \%$ & Utilities & 2 & $2 \%$ \\
\hline 2004 & 6 & $5 \%$ & Technology & 16 & $14 \%$ \\
\hline 2005 & 6 & $5 \%$ & & & \\
\hline 2006 & 3 & $2 \%$ & & & \\
\hline 2007 & 0 & $0 \%$ & & & \\
\hline 2008 & 6 & $5 \%$ & & & \\
\hline 2009 & 9 & $8 \%$ & & & \\
\hline 2010 & 5 & $4 \%$ & & & \\
\hline Total & 116 & $100 \%$ & Total & 116 & $100 \%$ \\
\hline
\end{tabular}


Table 2

Descriptive statistics and univariate analysis

\begin{tabular}{|c|c|c|c|c|c|c|c|c|}
\hline \multirow[b]{2}{*}{ Variables } & \multicolumn{3}{|c|}{$\begin{array}{l}\text { Going-concern Modifications } \\
\qquad(\mathrm{n}=39)^{(4)} \\
\end{array}$} & \multicolumn{3}{|c|}{$\begin{array}{c}\text { Clean Opinions } \\
(\mathrm{n}=77)\end{array}$} & \multirow[b]{2}{*}{$\begin{array}{c}\text { T-test/ } \\
\text { Chi-square }\end{array}$} & \multirow[b]{2}{*}{$\begin{array}{l}\text { Mann- } \\
\text { Whitney }\end{array}$} \\
\hline & Mean & Median & Std dev & Mean & Median & Std dev & & \\
\hline AC_INED & 76.50 & 100 & 31.87 & 64.63 & 66.67 & 35.69 & $-1.75 * *$ & $-1.83 *$ \\
\hline EXPERT & 50.00 & 50.00 & 25.58 & 30.02 & 33.33 & 27.60 & $-3.77 * * *$ & $-3.41 * * *$ \\
\hline FEERATIO & 1.72 & 1.01 & 2.12 & 1.87 & 1.00 & 2.47 & 0.33 & 0.64 \\
\hline AC_SIZ & 2.62 & 3.00 & 0.67 & 2.83 & 3.00 & 0.70 & 1.59 & 1.62 \\
\hline REPORTLAG & 133.28 & 122 & 39.18 & 101.52 & 99 & 34.48 & $-4.48 * * *$ & $-4.08 * * *$ \\
\hline TENURE & 5.72 & 6.00 & 3.04 & 6.22 & 6.00 & 2.88 & 0.87 & 0.81 \\
\hline BIGN & 0.74 & & 0.44 & 0.75 & & 0.43 & 0.01 & \\
\hline COM_SIZ (million) & 78.40 & 33.60 & 125.91 & 129.83 & 41.53 & 215.26 & 1.38 & $1.68 *$ \\
\hline COMPLEX & 21.84 & 12.5 & 27.92 & 24.77 & 20 & 27.54 & 0.53 & 0.48 \\
\hline LOSS & 0.82 & & & 0.53 & & & $9.21 * * *$ & \\
\hline LEV & 0.41 & 0.33 & 0.48 & 0.29 & 0.29 & 0.22 & $-1.86 *$ & -1.25 \\
\hline PRIOR & 0.36 & & 0.49 & 0.01 & & 0.11 & $27.52 * * *$ & \\
\hline CRISIS & 0.15 & & & 0.17 & & & 0.14 & \\
\hline
\end{tabular}

Notes: $(1)^{* * *},{ }^{* *}$ and * indicate significance at the $1 \%(p<0.01)$, at the 5\% $(p<0.05)$ and at the $10 \%(p<0.10)$ levels, respectively. (2) AC_INED: the percentage of audit committee members who are independent directors; EXPERT: the percentage of members with financial expertise on the audit committee; FEERATIO: the ratio of auditor-provided NAS fees to audit services fees; AC_SIZ: number of audit committee members; REPORTLAG: number of days from the end of the year to the audit report date; TENURE: length of auditor-client relationship in years; BIGN: a dummy variable with a value of 1 if the company was audited by a Big 4/5 audit firm, 0 otherwise; LnCOM_SIZ: natural log of total assets (proxy for firm size); COMPLEX: the percentage of foreign subsidiaries in total subsidiaries; LOSS: a dummy variable with a value of 1 if the company reported negative net income for the fiscal year, 0 otherwise; LEV: the ratio of total debt to total assets; PRIOR: a dummy variable with a value of 1 if the company received a going-concern modification in the preceding year, 0 otherwise; CRISIS: a dummy variable with a value of 1 if the last audit opinion date prior to failure was after 31 December 2007, 0 otherwise. (3) T-tests and Mann-Whitney tests for continuous variables; and chi-square tests for categorical variables (SWITCH, BIGN, LOSS, PRIOR and CRISIS). (4) Among the 39 companies which were issued with an auditor going-concern modification, 2 received a qualified opinion and 37 received an emphasis of matter paragraph highlighting the existence of material going-concern uncertainty. 
Table 3

Spearman correlation matrix

\begin{tabular}{|c|c|c|c|c|c|c|c|c|c|c|c|c|c|}
\hline & 1 & 2 & 3 & 4 & 5 & 6 & 7 & 8 & 9 & 10 & 11 & 12 & 13 \\
\hline 1 AC_INED & $0.37 * * *$ & 1.00 & & & & & & & & & & & \\
\hline 2 EXPERT & 0.07 & 0.12 & 1.00 & & & & & & & & & & \\
\hline 3 FEERATIO & $0.17 *$ & $0.19 * *$ & -0.11 & 1.00 & & & & & & & & & \\
\hline 4 AC_SIZ & -0.14 & $-0.26 * * *$ & $-0.24 * * *$ & -0.07 & 1.00 & & & & & & & & \\
\hline 5 REPORTLAG & -0.14 & -0.01 & -0.06 & -0.06 & $-0.18 *$ & 1.00 & & & & & & & \\
\hline 6 TENURE & $0.21 * *$ & $0.19 * *$ & -0.08 & $0.18 *$ & $-0.16 *$ & 0.03 & 1.00 & & & & & & \\
\hline 7 BIGN & 0.13 & -0.02 & -0.12 & 0.12 & 0.08 & -0.02 & 0.06 & 1.00 & & & & & \\
\hline 8 LnCOM_SIZ & $0.16 *$ & 0.15 & 0.01 & $0.18 *$ & 0.11 & $-0.27 * * *$ & $0.20 * *$ & 0.14 & 1.00 & & & & \\
\hline 9 COMPLEX & -0.02 & 0.08 & -0.09 & 0.05 & -0.04 & 0.02 & 0.05 & 0.12 & $0.38 * * *$ & 1.00 & & & \\
\hline 10 LOSS & -0.06 & 0.06 & -0.04 & 0.07 & -0.05 & $0.26 * * *$ & -0.01 & 0.01 & $-0.35 * * *$ & -0.05 & 1.00 & & \\
\hline $11 \mathrm{LEV}$ & -0.04 & 0.06 & 0.11 & 0.03 & -0.10 & $0.18 *$ & 0.09 & 0.05 & $0.29 * * *$ & 0.08 & $-0.19 * * *$ & 1.00 & \\
\hline 12 PRIOR & -0.07 & 0.10 & $0.18 * *$ & 0.03 & -0.10 & $0.17 *$ & 0.00 & 0.04 & -0.10 & -0.07 & $-0.15 * *$ & -0.02 & 1.00 \\
\hline 13 CRISIS & -0.04 & 0.07 & $0.17 *$ & -0.05 & -0.01 & $-0.18 * *$ & 0.07 & 0.05 & $0.34 * * *$ & $0.17 *$ & $0.12 *$ & -0.12 & -0.04 \\
\hline
\end{tabular}

Notes: $(1) * * *, * *$ and $*$ indicate a significant relationship at the $1 \%(p<0.01), 5 \%(p<0.05)$ and $10 \%(p<0.10)$ levels, respectively. (2) AC_INED: the percentage of audit committee members who are independent directors; EXPERT: the percentage of members with financial expertise on the audit committee; FEERATIO: the ratio of auditor-provided NAS fees to audit services fees; AC SIZ: number of audit committee members; REPORTLAG: number of days from the end of the year to the audit report date; TENURE: length of auditor-client relationship in years; BIGN: a dummy variable with a value of 1 if the company was audited by a Big $4 / 5$ audit firm, 0 otherwise; LnCOM_SIZ: natural log of total assets (proxy for firm size); COMPLEX: the percentage of foreign subsidiaries in total subsidiaries; LOSS: a dummy variable with a value of 1 if the company reported negative net income for the fiscal year, 0 otherwise; LEV: the ratio of total debt to total assets; PRIOR: a dummy variable with a value of 1 if the company received a going-concern modification in the preceding year, 0 otherwise. CRISIS: a dummy variable with a value of 1 if the last audit opinion date prior to failure was after 31 December 2007, 0 otherwise. 
Table 4

Logistic regression of the associations of audit committee characteristics and non-audit services (NAS) fees with the likelihood of going-concern modifications

\begin{tabular}{|c|c|c|c|}
\hline $\begin{aligned} & G C M= \beta_{0}+\beta_{1} A C \_I N E D_{i}+\beta_{2} E X P E \\
&+\beta_{7} B I G N_{i}+\beta_{8} L n C O M_{-} S I Z_{i} \\
&\end{aligned}$ & $\begin{array}{l}\mathrm{ATIO}_{i}+\beta \\
{ }_{i}+\beta_{10} \mathrm{LC}\end{array}$ & $\begin{array}{l}\text { REPORTL } \\
{ }_{i}+\beta_{12} \text { PRIC }\end{array}$ & $\begin{array}{l}\text { JURE } \\
S_{i} \\
S_{i}+e_{i}\end{array}$ \\
\hline & (1) & (2) & (3) \\
\hline AC_INED & $0.019 * *$ & $0.017 * * *$ & $0.020 * *$ \\
\hline & $(0.009)$ & $(0.007)$ & $(0.009)$ \\
\hline EXPERT & $0.040 * *$ & $0.039 * * *$ & $0.040 * *$ \\
\hline & $(0.016)$ & $(0.012)$ & $(0.016)$ \\
\hline FEERATIO & -0.167 & 0.071 & -0.157 \\
\hline & (0.197) & (0.123) & $(0.208)$ \\
\hline AC_SIZ & -0.062 & 0.116 & -0.084 \\
\hline & $(0.499)$ & $(0.424)$ & $(0.492)$ \\
\hline REPORTLAG & $0.025 * * *$ & $0.026 * * *$ & $0.025^{* * *}$ \\
\hline & $(0.010)$ & $(0.010)$ & $(0.009)$ \\
\hline TENURE & -0.108 & -0.085 & -0.126 \\
\hline & $(0.104)$ & (0.088) & (0.103) \\
\hline BIGN & -0.171 & 0.230 & -0.125 \\
\hline & $(0.682)$ & $(0.631)$ & $(0.690)$ \\
\hline LnCOM_SIZ & 0.040 & -0.231 & 0.092 \\
\hline & $(0.256)$ & $(0.246)$ & $(0.259)$ \\
\hline COMPLEX & 0.004 & 0.004 & 0.003 \\
\hline & $(0.013)$ & $(0.010)$ & $(0.013)$ \\
\hline LOSS & $3.088 * * *$ & $1.467 * *$ & $3.045^{* * *}$ \\
\hline & $(0.752)$ & $(0.593)$ & $(0.725)$ \\
\hline LEV & 0.781 & $1.288 * *$ & 0.758 \\
\hline & $(0.869)$ & $(0.553)$ & (0.918) \\
\hline PRIOR & $4.760 * * *$ & & $4.646 * * *$ \\
\hline & (1.504) & & $(1.462)$ \\
\hline CRISIS & 0.501 & 0.230 & \\
\hline & $(0.779)$ & $(0.622)$ & \\
\hline Constant & $-8.995 * * *$ & $-7.447 * * *$ & $-8.900 * * *$ \\
\hline & (3.279) & $(2.647)$ & (3.213) \\
\hline Observations & 116 & 116 & 116 \\
\hline Model chi-square & $29.76^{* * *}$ & $29.54 * * *$ & $29.48 * * *$ \\
\hline Pseudo R-square & 0.4931 & 0.3425 & 0.4909 \\
\hline Classification rate (\%) & & & \\
\hline Going-concern modifications & 74.36 & 66.67 & 79.49 \\
\hline Clean opinions & 90.91 & 88.31 & 92.21 \\
\hline Overall & 85.34 & 81.03 & 87.93 \\
\hline
\end{tabular}

Notes: $(1) * * *$,** and * indicate a significant relationship at the $1 \%(p<0.01), 5 \%(p<0.05)$ and $10 \%$ levels, respectively. Robust standard errors are in parentheses. (2) AC_INED: the percentage of audit committee members who are independent directors; EXPERT: the percentage of members with financial expertise on the audit committee; FEERATIO: the ratio of auditor-provided NAS fees to audit services fees; AC_SIZ: number of audit committee members; REPORTLAG: number of days from the end of the year to the audit report date; TENURE: length of auditor-client relationship in years; BIGN: a dummy variable with a value of 1 if the company was audited by a Big 4/5 audit firm, 0 otherwise; LnCOM_SIZ: natural log of total assets (proxy for firm size); COMPLEX: the percentage of foreign subsidiaries in total subsidiaries; LOSS: a dummy variable with a value of 1 if the company reported negative net income for the fiscal year, 0 otherwise; LEV: the ratio of total debt to total assets; PRIOR: a dummy variable with a value of 1 if the company received a going-concern modification in the preceding year, 0 otherwise. CRISIS: a dummy variable with a value of 1 if the last audit opinion date prior to failure was after 31 December 2007, 0 otherwise. 
Table 5

Results for interactive effects of audit committee characteristics and non-audit services (NAS) fees on the likelihood of going-concern opinions

Panel A: Logistic regression

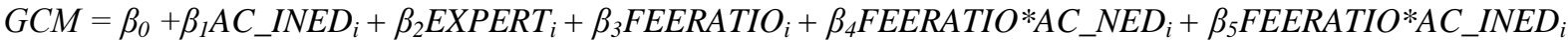

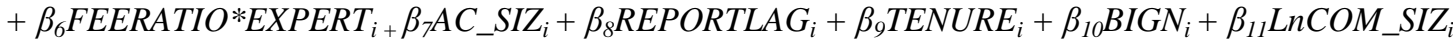

$+\beta_{12} \mathrm{COMPLEX}_{i}+\beta_{13} \mathrm{LOSS}_{i}+\beta_{14} \mathrm{LEV}_{i}+\beta_{15}$ PRIOR $_{i}+\beta_{16} \mathrm{CRISIS}_{i}+e_{i}$

\begin{tabular}{|c|c|c|}
\hline Variables & (1) & (2) \\
\hline AC_INED & $\begin{array}{l}0.041^{* *} \\
(0.018)\end{array}$ & $\begin{array}{l}0.016^{*} \\
(0.009)\end{array}$ \\
\hline EXPERT & $\begin{array}{l}0.036^{* *} \\
(0.016)\end{array}$ & $\begin{array}{l}0.056^{* * *} \\
(0.015)\end{array}$ \\
\hline FEERATIO & $\begin{array}{l}-0.807 * \\
(0.401)\end{array}$ & $\begin{array}{l}-0.373 \\
(0.245)\end{array}$ \\
\hline FEERATIO* AC_INED & $\begin{array}{l}0.025^{* *} \\
(0.013)\end{array}$ & \\
\hline FEERATIO*EXPERT & & $\begin{array}{l}0.027 * * \\
(0.011)\end{array}$ \\
\hline AC_SIZ & $\begin{array}{l}0.014 \\
(0.524)\end{array}$ & $\begin{array}{l}-0.075 \\
(0.527)\end{array}$ \\
\hline REPORTLAG & $\begin{array}{l}0.024 * * * \\
(0.009)\end{array}$ & $\begin{array}{l}0.026^{* * *} \\
(0.009)\end{array}$ \\
\hline TENURE & $\begin{array}{l}-0.105 \\
(0.108)\end{array}$ & $\begin{array}{l}-0.086 \\
(0.114)\end{array}$ \\
\hline BIGN & $\begin{array}{l}-0.255 \\
(0.734)\end{array}$ & $\begin{array}{l}-0.069 \\
(0.765)\end{array}$ \\
\hline LnCOM_SIZ & $\begin{array}{l}0.075 \\
(0.270)\end{array}$ & $\begin{array}{l}-0.040 \\
(0.292)\end{array}$ \\
\hline COMPLEX & $\begin{array}{l}0.005 \\
(0.012)\end{array}$ & $\begin{array}{l}0.006 \\
(0.014)\end{array}$ \\
\hline LOSS & $\begin{array}{l}3.132 * * * \\
(0.706)\end{array}$ & $\begin{array}{l}3.494 * * * \\
(0.939)\end{array}$ \\
\hline LEV & $\begin{array}{l}0.910 \\
(0.971)\end{array}$ & $\begin{array}{l}0.456 \\
(0.975)\end{array}$ \\
\hline PRIOR & $\begin{array}{l}4.539 * * * \\
(1.525)\end{array}$ & $\begin{array}{l}6.022 * * * \\
(1.096)\end{array}$ \\
\hline CRISIS & $\begin{array}{l}0.492 \\
(0.821)\end{array}$ & $\begin{array}{l}0.458 \\
(0.869)\end{array}$ \\
\hline CONSTANT & $\begin{array}{l}-7.403^{* * *} \\
(2.421)\end{array}$ & $\begin{array}{l}-6.908 * * * \\
(2.478)\end{array}$ \\
\hline Observations & 116 & 116 \\
\hline Model chi-square & $39.40 * * *$ & $56.90 * * *$ \\
\hline Pseudo R-square & 0.5154 & 0.5314 \\
\hline Classification rate (\%) & & \\
\hline Going-concern modifications & 76.92 & 76.92 \\
\hline Clean opinions & 92.21 & 88.31 \\
\hline Overall & 87.07 & 84.48 \\
\hline
\end{tabular}

Panel B: Coefficient on (FEERATIO + FEERATIO*AC_NED), (FEERATIO+ FEERATIO*AC_INED), (FEERATIO + FEERATIO*EXPERT), by different values of AC_NED, AC_INED and EXPERT, respectively.

\begin{tabular}{|c|c|c|c|c|}
\hline Sample Distribution & AC_INED & & EXPERT & \\
\hline $25 \%$ percentiles & at $50 \%$ & $\begin{array}{l}-1.284^{* *} \\
(0.617)\end{array}$ & at $0 \%$ & $\begin{array}{l}-1.348 * * \\
(0.533)\end{array}$ \\
\hline $50 \%$ percentiles & at $66.67 \%$ & $\begin{array}{l}-0.856^{* *} \\
(0.422)\end{array}$ & at $33.33 \%$ & $\begin{array}{l}-0.463^{*} \\
(0.260)\end{array}$ \\
\hline 75\% percentiles & at $100 \%$ & $\begin{array}{l}-0.010 \\
(0.236)\end{array}$ & at $50 \%$ & $\begin{array}{l}-0.021 \\
(0.232)\end{array}$ \\
\hline
\end{tabular}


Notes: $(1) * * *, * *$ and * indicate a significant relationship at the $1 \%(p<0.01), 5 \%(p<0.05)$ and $10 \%$ levels, respectively. Robust standard errors are in parentheses. (2) Panel A shows the logistic regression for the effect of the interaction terms between AC_IND, EXPERT and FEERATIO on the likelihood of a going-concern modification. AC_INED, EXPERT and FEERATIO have been mean-centred. FEERATIO*AC NED: the interaction term between FEERATIO and AC_NED; FEERATIO*AC_INED: the interaction term between FEERATIO and AC_INED; FEERATIO*EXPERT: the interaction term between FERATIO and EXPERT. See Table 3 for definitions of the other variables. (3) Panel B shows how the impact of FEERATIO on the likelihood of a going-concern modification varies with different values of AC_NED, AC_INED and EXPERT. (4) The models shown in this table are developed by extending Model (1) of Table 4. The results are substantively the same after the deletion of PRIOR and CRISIS as Models (2) and (3) shown in Table 4, respectively. 